\title{
A Walk on the Wild Side: 2021 Cool-Season Forage Recommendations for Wildlife Food Plots in North Florida'
}

\author{
M. Wallau, A. R. Blount, J. M. Campos-Krauer, M. A. Lashley, E. Rios, J. M. B. Vendramini, J. C. B. \\ Dubeux, Md. A. Babar, C. L. Mackowiak, and K. H. Quesenberry²
}

Food plots are very popular with hunters, for supplementing diets or attracting wildlife. Cool-season forages can also represent a great feed source for captive, farm deer, a fast-growing industry in rural America. A large portion of sales of cool-season forage seeds is dedicated to the establishment of wildlife plots. Establishment of those plots, however, can be challenging and frustrating if proper practices are not followed. Establishment failures are generally related to low soil $\mathrm{pH}$, poor performing varieties, lack of fertilization, and early grazing. Most hunters choose a spot in or close to the woods, where normally the native $\mathrm{pH}$ is low and light may be limiting to forage plant growth. Soil testing is essential to evaluate $\mathrm{pH}$ and levels of nutrients, which will determine any need for liming and fertilizer. Information on soil testing is available at https:// edis.ifas.ufl.edu/topic_soil_testing. Multiple hunting and hardware stores sell nicely packed and small-sized seed mixes for wildlife. However, many of those mixes contain poor performing varieties or species that will not grow in Florida. Hence, following the recommendation list below and sourcing seeds locally (with seed retailers) is often a better and less expensive choice. Forage blends are generally beneficial for the plot's longevity and stability and can be a resource for multiple wildlife species. Finally, installing exclusion fence until the plots are well established prevents early grazing and overgrazing. The following list of cool-season forage recommendations for wildlife includes varieties that have been tested and are known to perform well in Florida.

\section{Cool-Season Legumes}

Winter legumes are more productive and dependable in the heavier clay soils of northwest Florida or in sandy soils that are underlain by a clay layer than in deep upland sands or sandy flatwoods. Inoculation of legumes is very important because it eliminates the need to supply nitrogen. Certain plants will manufacture nitrogen if the proper inoculant (Rhizobium bacteria) is used. Many clovers and alfalfas come pre-inoculated. If the legumes you intend to use are not pre-inoculated, there are commercially available inoculants that are specific to each legume variety.

1. This document is SS-AGR-28, one of a series of the Agronomy Department, UF/IFAS Extension. Original publication date April 2002. Revised October 2021. Visit the EDIS website at https://edis.ifas.ufl.edu for the currently supported version of this publication.

2. M. Wallau, assistant professor, Agronomy Department; A. R. Blount, professor, Agronomy Department, UF/IFAS North Florida Research and Education Center; J. M. Campos-Krauer, assistant professor, Department of Large Animal Clinical Sciences \& Department of Wildlife Ecology and Conservation; M. A. Lashley, assistant professor, Department of Wildlife Ecology and Conservation; E. Rios, associate professor, Agronomy Department; J. M. B. Vendramini, professor, Agronomy Department, UF/IFAS Range Cattle Research and Education Center; J. C. B. Dubeux, associate professor, Agronomy Department, UF/IFAS NFREC; Md. A. Babar, assistant professor, Agronomy Department; C. L. Mackowiak, associate professor, Department of Soil and Water Sciences, UF/IFAS NFREC; and K. H. Quesenberry, professor emeritus, Agronomy Department; UF/IFAS Extension, Gainesville, FL 32611.

The use of trade names in this publication is solely for the purpose of providing specific information. UF/IFAS does not guarantee or warranty the products named, and references to them in this publication do not signify our approval to the exclusion of other products of suitable composition.

The Institute of Food and Agricultural Sciences (IFAS) is an Equal Opportunity Institution authorized to provide research, educational information and other services

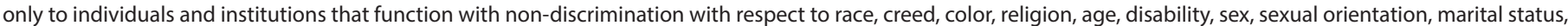

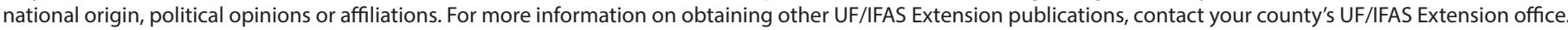
U.S. Department of Agriculture, UF/IFAS Extension Service, University of Florida, IFAS, Florida A \& M University Cooperative Extension Program, and Boards of County Commissioners Cooperating. Nick T. Place, dean for UF/IFAS Extension. 


\section{ALFALFA}

This high-quality legume is usually grown as a winter, short-lived perennial forage in Florida. It is, however, very challenging to grow and not recommended for most soils or production systems in Florida. Several new varieties have been selected under grazing by cattle and are low- or nondormant types. Low dormancy means that the alfalfa will sprout and grow in our mild winter climate. Many commercially available food plot blends include mid- or highdormancy alfalfas that do not grow well in the southern United States. Alfalfa requires a soil pH of 6.5-7.0, high soil fertility, well-drained soils, and good management, making it difficult to manage in wildlife food plot situations.

Not recommended. Adapted varieties for north Florida are Bulldog 805 and Alfagraze 600RR.

\section{ARROWLEAF CLOVER}

This is an annual clover similar to crimson clover in soil adaptation, management, and fertility requirements. It is mainly grown in heavier soils in northwest Florida. It is more productive than crimson clover in late spring as a deer forage. However, the later maturation is not as suitable for turkeys in late spring nor for brooding.

Recommended varieties are Blackhawk and Apache. Yuchi is susceptible to bean yellow mosaic virus.

\section{BALL CLOVER}

This is an annual clover that grows on a wide range of soil types, including poorly drained soils. It is well adapted, capable of reseeding readily, and considered an excellent clover for wildlife in Florida. It is highly preferable for deer and moderate for turkeys.

Recommended varieties are Don, Grazer's Select, and Segrest.

\section{BERSEEM AND OTHER MISCELLANEOUS CLOVERSANDMEDICS}

There are many other small-seeded clovers, including rose, berseem, hop, bur, and subterranean clover, which will work fairly well for wildlife food plots. Limited local seed availability or high seed costs may be limiting factors. Generally, these clovers produce less forage for deer than crimson, white, arrowleaf, and red clover and have a short growing season. They do, however, provide a better opportunity for brooding turkeys because the early maturation allows native forbs to colonize late spring and early summer similar to crimson. Ball, Persian, and hop clovers reseed well.

Recommended varieties include Bigbee and Frosty berseem, Armadillo medic, and Devine Little burand Overton rose clovers.

\section{RED CLOVER}

This clover behaves as a winter annual under most north Florida conditions. Some reseeding may occur. Nondormant varieties are recommended. Red clover does not tolerate flooding. The later maturation is excellent for deer forage production, and it is preferred by adult turkeys in the spring.

Recommended varieties are Southern Belle, Bulldog Red, Barduro, and Red Ace. Southern Belle and Barduro were developed in Florida.

\section{CRIMSON CLOVER}

This is a well-adapted legume for north Florida. It is an excellent forage producer and can reseed itself each year if weather conditions permit. It is an annual clover that is adapted to fertile, well-drained soil. Of the clovers, it appears to be the least sensitive to soil $\mathrm{pH}$. It has a relatively short grazing season, so it may be grown in combination with clovers or a small grain crop to extend the period of forage availability. The early maturation makes it highly conducive to colonization by native annual forbs such as common ragweed that support high insect production and excellent structure during brooding for turkeys and northern bobwhite. This is the most versatile clover in terms of successfully balancing deer forage production and attraction with turkey and quail use.

Recommended varieties are Dixie, AU-Sunrise, and AU-Robin.

\section{VETCH}

Vetch grows best in well-drained, fertile, loamy soils. It has a spreading, viny growth habit, is an annual plant, and can easily form a thick mat taking over the food plot area. The plant reseeds itself fairly well. Many wildlife species consume the seed and foliage. There are two main species of vetch: hairy (Vicia vilosa) and common (Vicia sativa). Deer have moderate preference for vetch as a forage. Neither species of vetch is desirable for upland gamebirds.

Recommended varieties are AU Early Cover, Cahaba White, Hairy, AU-Merit, and Nova II. Commercial seed 
production of most vetch varieties is limited. It may be necessary to special order seed.

\section{WHITE CLOVER}

White clover in Florida is usually a winter annual, but it may act as a short-term perennial under optimal fertility and moisture conditions. It is adapted to moist soils throughout Florida and reseeds well. Nematodes and other pests can limit production. Both deer and turkey have a high preference for white clover as a forage during spring.

Recommended varieties are Ocoee and Osceola, Louisiana S-1, Barblanca, Regalgraze, and Regal Ladino. Durana is also well adapted, having a prostrate growth habit and longevity.

\section{WINTER PEAS}

This annual legume is best suited to well-drained soils with high clay content. Deer preference is high. The legume does not tolerate heavy grazing and is not very cold hardy.

Recommended varieties are Austrian, Whistler, and Maple. Several new varieties are commercially available and may be well suited for wildlife food plots in this region, but these have not been broadly evaluated.

\section{Cool-Season Grasses}

Recommended cool-season grasses for wildlife include the small grains: wheat, oat, rye, and triticale.These grasses provide excellent winter forage and a spring seed crop which wildlife readily utilize, but the grasses generally require nitrogen fertilizer inputs to be productive. Ryegrass, a common forage alternative for livestock, is normally not recommended for wildlife plots.

\section{OAT}

Oat may be planted and grazed by wildlife earlier than rye (except FL401 rye). When seeded in mid-fall, oat should produce very palatable forage by late fall, but it will be more susceptible to diseases in hot fall weather. Oats are not as cold hardy as rye or wheat and may be susceptible to freeze injury. It is important to choose recommended oat varieties. Many feed oats are sold and planted as seed oats, but they often do not have a guarantee on the percent germination. Feed oats also may not have any resistance to the heavy disease pressure in Florida, particularly from rust and virus.

Recommended varieties include Big Boss Wildlife Forage Oat, Horizon 306, Horizon 720, Plot Spike LA 9339, Ram LA99016, Legend 567, and Buck Forage. It would be optimal to choose an oat variety with improved crown rust resistance, winter hardiness, and good grain and forage production for wildlife interests in our area.

\section{RYE}

Rye is widely used for winter grazing for cattle, but it may be grazed by deer as well. Rye is more cold tolerant than oat and generally produces more forage than either oat or wheat. Rye should not be planted as early as oat due to several diseases occurring in the early fall. It is best to wait for cool weather before planting, around mid-November.

Recommended varieties are FL 401 (for early grazing or for use in blends), Kelly Grazer III (FL 104), Wrens Abruzzi, Bates RS4, and Elbon. Other commercial varieties may be adapted but have not been included in our variety trials in recent years.

\section{WHEAT}

Wheat is excellent for wildlife, but not well adapted to Florida conditions. Low productivity and high incidence of diseases are common. Hessian fly can be an issue, so recommended varieties should be Hessian fly-tolerant. Deer prefer the forage, and some nongame birds utilize the seed. The seed head on awnless varieties get substantial use from deer, turkeys, and mourning doves.

AGS 2024 (moderate tolerance to Hessian fly), Johnson, AGS GrazeAll (AGS2027)*†, Pioneer 26R10*, Dyna-Gro Plantation*.

*Varieties not recently tested but previously recommended. ${ }^{\dagger}$ Moderate tolerance to Hessian fly; consider insecticide management.

\section{RYEGRASS}

Ryegrass is a valuable and hardy forage crop for use on flatwoods soils or the heavier sandy loam soils in northwest Florida for cattle. In wildlife food plots, ryegrass may become a weed problem and dominate the food plot. It is also low preference for deer and extremely low preference for upland gamebirds. Ryegrass also tends to reseed and may germinate the following year. There are many well-adapted ryegrass varieties on the commercial market. However, we do not recommend their use in wildlife food plot mixes.

\section{TRITICALE}

This is a very high-quality, robust small grain that resulted from a cross of wheat and rye. It is very well-adapted to 
north Florida, has good disease and insect resistance, and grows well even when late-planted in December and January. Deer preference is moderate to high and provides complementary structure for upland game birds when mixed with early-maturing clovers.

TriCal 342, TriCal 1143*, and TriCal Marlin Max.

${ }^{\star}$ Awnless varieties recommended for wildlife but might be in short supply this season.

\section{Brassica and Forage Chicory Crops}

Brassicas are annual crops that are highly productive and digestible and can provide forage as quickly as 40 days after seeding, depending on the species. Forage brassica crops such as turnip, swede, rape, and kale can be both fall- and spring-seeded. Little is known about the adaptability of forage brassicas to Florida. Deer preference for these forages is highly variable across sites, most likely as a result of the high sulfur content. Gamebird use is relatively low when planted alone, but brassicas do support high insect production when mixed with a cereal grain and early-maturing clover.

\section{KALE (Brassica Oleracea L. ACEPHALA GROUP)}

Kale is very winter-hardy. Recommended varieties include Premier, Vates, and Siberian.

\section{RAPE (Brassica Napus L.)}

Rape is very winter-hardy.

Recommended varieties include Rangi, Rangiora, Barnapoli, Dwarf Essex, Emerald, and Winfred.

\section{TURNIP (Brassica Rapa L.) OR TURNIP HYBRIDS}

These crops grow very quickly, reaching near maximum production levels in 80-90 days.

Varieties include Purple Top, White Globe, and Barkant. Some varieties such as All Top and Seven Top only produce tops.

\section{SWEDE (Brassica Napus L.)}

Like turnip, swedes produce a large edible root. Yields are higher than those of turnip; however, these grow slower and require 150-180 days to reach maximum production.

\section{DAIKON RADISH (Raphanus Sativus)}

This is a highly palatable brassica that is well-adapted to light, sandy soils. It is often referred to as tillage radish. Early planting may cause early bloom. Consider staggered planting dates to encourage longer season availability.

Recommended varieties are Trophy and Daikon radish.

\section{FORAGE CHICORY (Cichorium Intybus L.)}

This is a perennial plant (forb) that is suited to well-drained or moderately drained soils with medium to high fertility levels and a $\mathrm{pH}$ of 5.5 or greater. This forage is highly preferred by deer and supports high insect production when mixed with a cereal grain and early-maturing clover.

Varieties available at this time are Puna and Forage Feast.

\section{Recommended Cool-Season Forage Blends}

Use recommended varieties listed above and inoculate clovers with proper Rhizobium bacteria. Crimson clover is better adapted to well-drained sites, red clover to mediumdrained sites, and white and arrowleaf clover to wet or poorly drained sites.

\section{BEST VALUE}

- $50 \mathrm{lb}(2 \mathrm{bu})$ oats

- $50 \mathrm{lb}(1 \mathrm{bu})$ triticale

- $6 \mathrm{lb}$ red clover

- $15 \mathrm{lb}$ crimson clover

\section{DOUBLE TREAT}

For well-drained sites:

- $10 \mathrm{lb}$ red clover

- $15 \mathrm{lb}$ crimson clover

\section{TRIPLE TREAT}

For wet or poorly drained sites:

- $4 \mathrm{lb}$ white clover

- $12 \mathrm{lb}$ red clover

- $4 \mathrm{lb}$ arrowleaf clover

\section{TETRA TREAT}

For medium-drained and dry sites:

- $15 \mathrm{lb}$ crimson clover

- $6 \mathrm{lb}$ red clover

- $4 \mathrm{lb}$ arrowleaf clover

- $2 \mathrm{lb}$ white clover 
Table 1. Planting dates, seeding rates, planting depths, and grazing parameters for certain cool-season forage crops.

\begin{tabular}{|c|c|c|c|c|c|c|}
\hline \multirow{2}{*}{$\begin{array}{c}\text { Seed- } \\
\text { Propagated } \\
\text { Crops }^{1}\end{array}$} & \multirow[t]{2}{*}{ Planting Dates ${ }^{2}$} & \multirow{2}{*}{$\begin{array}{l}\text { Seeding Rates } \\
\text { (Ib/A broadcast) }\end{array}$} & \multirow{2}{*}{$\begin{array}{l}\text { Seeding Depth } \\
\text { (in) }\end{array}$} & \multicolumn{2}{|c|}{ Grazing Height (in) } & \multirow{2}{*}{$\begin{array}{c}\text { Rest Period } \\
\text { (days) }\end{array}$} \\
\hline & & & & Beginning & End & \\
\hline Alfalfa & Oct. 1-Nov. 15 & $15-20$ & $1 / 4-1 / 2$ & $10-16$ & $3-4$ & $15-30$ \\
\hline Clover, Arrowleaf & Oct. 1-Nov. 15 & $8-12$ & $0-1 / 2$ & $8-10$ & $3-5$ & $10-20$ \\
\hline Clover, Ball & Oct. 1-Nov. 15 & $2-3$ & $0-1 / 4$ & $6-8$ & $1-3$ & $7-15$ \\
\hline Clover, Berseem & Oct. 1-Nov. 15 & $15-20$ & $1 / 4-1 / 2$ & $8-10$ & $3-5$ & $10-20$ \\
\hline Clover, Crimson & Oct. 1-Nov. 15 & $20-25$ & $1 / 4-1 / 2$ & $8-10$ & $3-5$ & $10-20$ \\
\hline Clover, Red & Oct. 1-Nov. 15 & $10-15$ & $1 / 4-1 / 2$ & $8-10$ & $3-5$ & $10-20$ \\
\hline $\begin{array}{l}\text { Clover, } \\
\text { Subterranean }\end{array}$ & Oct. 1-Nov. 15 & $15-20$ & $1 / 4-1 / 2$ & $6-8$ & $1-3$ & $7-15$ \\
\hline Clover, White & Oct. 1-Nov. 15 & $3-4$ & $0-1 / 4$ & $6-8$ & $1-3$ & $7-15$ \\
\hline Fescue, Tall & Nov. 1-Dec. 15 & $20-25$ & $1 / 4-1 / 2$ & $4-8$ & $2-3$ & $15-30$ \\
\hline Medic & Oct. 1-Nov. 15 & $\begin{array}{l}\text { 10-15 (rates } \\
\text { differ) }\end{array}$ & $0-1 / 4$ & $6-8$ & $1-3$ & $7-15$ \\
\hline Oats for forage & Sept. 15-Nov. 15 & $100-120$ & $1-2$ & $8-12$ & $3-5$ & $7-15$ \\
\hline $\begin{array}{l}\text { Pea, Austrian } \\
\text { Winter }\end{array}$ & Oct. 1-Nov. 15 & $40-60$ & $1 / 2-1$ & \multicolumn{3}{|c|}{ Poor grazing tolerance. } \\
\hline Rye for forage & Oct. 15-Nov. 15 & $90-120$ & $1-2$ & $8-12$ & $3-4$ & $7-15$ \\
\hline Sweetclover & Oct. 1-Nov. 15 & $10-15$ & $1 / 4-1 / 2$ & $8-10$ & $3-5$ & $10-20$ \\
\hline Turnips & Oct. 1-Nov. 15 & $5-6$ & $1 / 4-1 / 2$ & $6-8$ & $2-3$ & varies \\
\hline Vetch, Hairy & Oct. 1-Nov. 15 & $20-30$ & $1-2$ & $6-8$ & $3-4$ & varies \\
\hline $\begin{array}{l}\text { Triticale for silage } \\
\text { or use in blends }\end{array}$ & Oct. 15-Nov. 15 & $90-120$ & $1-2$ & & & \\
\hline
\end{tabular}

